\title{
ANALISIS IKLAN SYNOPSIS IKLAN TOKOPEDIA VERSI "PASRAH" 2015
}

\author{
SITTI MAESURAH \\ Institut Agama Islam Negeri (IAIN) Bone \\ maesurah88@gmail.com
}

\begin{abstract}
Advertising is one of the most important things in supporting the success of the goods or services offered to the public. Television advertisements are one of the advertisements that are often seen by the public because of the excess audio visual effects. In modern society, there are hardly any people who are not preoccupied with advertising activities. This can help us to realize and understand how important it is to have an institution or institution that integrates all the components and mechanics involved in advertising. Because, advertising is used by everyone, not only by the users of consumer goods, but in essence related to the mass information system in the political, economic, social, cultural and technological fields. Each other interacts using the information system referred to and spread all the problems associated with the system, including religious issues. From this description, what synopsis of Tokopedia "Resign" ads will be explored. This research shows that Tokopedia advertisement is considered not effective enough to convey a message even though this advertisement is quite entertaining for some people. But the message conveyed was blurred because so many meanings could be created from the short 30 second ad. But at least this advertisement can still fulfill the function as brand awareness.
\end{abstract}

Keywords: Advertising, Synopsis, Marketing, Marketing Communication. 


\begin{abstract}
Abstrak
Iklan menjadi salah satu hal yang sangat penting dalatam menunjang keberhasilan barang atau jasa yang ditawarkan kepada masyarakant. Iklan televisi merupakan salah satu iklan yang sering kali dilihat oleh masyarakat karena kelebihan efek audio visualnya. Di dalam masyrakat modern, hampir tidak ada orang yang tidak disibukkan oleh kegiatan periklanan. Hal tersebut dapat membantu kita untuk mewujudkan dan memahami betapa pentingnya adanya suatu lembaga atau institusi yang memadukan segala komponen dan mekanik yang terlibat dalam periklanan. Sebab, periklanan digunakan oleh setiap orang, tidak hanya oleh orang-orang pengguna barang konsumtif saja, akan tetapi pada hakikatnya berkaitan dengan sistem informasi masa dalam bidang politik, ekonomi, sosial, budaya dan teknologi. Satu sama lain berinteraksi menggunakan sistem informasi dimaksud dan menyebarkan semua masalah yang terkait dengan sistem tersebut, termasuk masalah keagamaan. Dari urain tersebut, maka akan didalami seperti apa synopsis iklan Tokopedia "Pasrah". Penelitian ini menunjukkan bawah iklan Tokopedia dinilai masih belum cukup efektif untuk menyampaikan pesan meski iklan ini cukup menghibur untuk sebagian orang. Tetapi pesan yang disampaikan menjadi kabur sebab begitu banyak makna yang dapat tercipta dari iklan singkat berdurasi 30 detik tersebut. Namun setidaknya iklan ini tetap dapat memenuhi fungsi sebagai brand awareness.
\end{abstract}

Kata Kunci: Iklan, Synopsis, Pemasaran, Komunikasi Pemasaran.

\title{
PENDAHULUAN
}

Meskipun periklanan memiliki banyak pengertian pribadi, kita bisa menyetujui semuanya bahwa periklanan lebih banyak digunakan dalan sistem informasi masa di kalangan masyarakat untuk tujuan ekonomi. Baik perorangan atau kelompok, orang ingin menggunakan sistem informasi massa di dalam masyarakat agar bisa memberikan atau memperoleh informasi dan akhirnya, membeli atau menjual berbagai macam barang atau jasa. Sebagai lembaga kemasyarakatan, periklanan telah menjadi sangat kompleks dan sebagai sistem teknologi komunikasi masa periklanan telah bermanfaat. Perorangan maupun kelompok semakin sering menggunkan komunikasi massa untuk tujuan ekonomi, misalnya untuk jual beli barang, pelayanan (servis) kepada publik, jual beli gagasan atau jasa. Sungguh peningkatan manfaat yang mengejutkan. 
Di dalam masyrakat modern, hampir tidak ada orang yang tidak disibukkan oleh kegiatan periklanan. Hal tersebut dapat membantu kita untuk mewujudkan dan memahami betapa pentingnya adanya suatu lembaga atau institusi yang memadukan segala komponen dan mekanik yang terlibat dalam periklanan. Sebab, periklanan digunakan oleh setiap orang, tidak hanya oleh orang-orang pengguna barang konsumtif saja, akan tetapi pada hakikatnya berkaitan dengan sistem informasi masa dalam bidang politik, ekonomi, sosial, budaya dan teknologi. Satu sama lain berinteraksi menggunakan sistem informasi dimaksud dan menyebarkan semua masalah yang terkait dengan sistem tersebut, termasuk masalah keagamaan. Dari urain tersebut, maka akan didalami seperti apa synopsis iklan Tokopedia "Pasrah"

\section{TINJAUAN PUSTAKA}

\section{Komunikasi Pemasaran}

Pemasaran adalah bekerja dengan pasar sasaran untuk mewujudkan pertukaran yang potensial dengan maksud memuaskan kebutuhan dan keinginan manusia. (Kotler, 2001) Sehingga dapat dikatakan bahwa keberhasilan pemasaran merupakan kunci kesuksesan dari suatu perusahaan. Pemasaran merupakan salah satu kegiatan pokok yang perlu dilakukan oleh perusahaan baik itu perusahaan barang atau jasa dalam upaya untuk mempertahankan kelangsungan hidup usahanya.

Hal tersebut disebabkan karena pemasaran merupakan salah satu kegiatan perusahaan, di mana secara langsung berhubungan dengan konsumen. Maka kegiatan pemasaran dapat diartikan sebagai kegiatan manusia yang berlangsung dalam kaitannya dengan pasar. Pemasaran adalah suatu sistem keseluruhan dari kegiatankegiatan bisnis yang ditujukan untuk merencanakan, menentukan harga, mempromosikan dan mendistribusikan barang atau jasa yang memuaskan kebutuhan baik kepada pembeli yang ada maupun pembeli potensial. Kedua penjelasan di atas mengenai pemasaran menjelaskan bahwa perusahaan dituntut tidak hanya fokus terhadap laba saja namun juga harus dapat memenuhi kebutuhan masyarakat agar 
perusahaan dapat terus berjalan dan dapat mengalahkan pesaing-pesaingnya. ${ }^{1}$

Komunikasi adalah proses dimana pemikiran dan pemahaman disampaikan antar individu, atau antar organisasi dengan individu. Pemasaran adalah sekumpulan kegiatan dimana perusahaan dan organisasi lainnya mentransfer nilai-nilai (pertukaran) antara mereka dengan pelanggannya. Sedangkan komunikasi pemasaran mempresentasikan gabungan semua unsur dalam bauran pemasaran merek yang memfasilitasi terjadinya pertukaran dengan menciptakan suatu arti yang disebarluaskan kepada pelanggan atau kliennya. Definisi komunikasi pemasaran adalah penyampaian pesan kepada masyarakat bahwa produk perusahaan berada di pasar. Komunikasi pemasaran memegang peranan penting bahwa tanpa adanya komunikasi masyarakat tidak akan mengetahui produk tersebut berada di pasar.

Komunikasi pemasaran memegang peran penting dalam pemasaran. Perusahaan dalam melakukan komunikasi pemasaran harus hati-hati dalam menentukan siapa sasaran potensialnya. Dengan menentukan sasaran potensial perusahaan dapat menyampaikan pesan dengan efektif dan efisien. Menurut Sutisna (2001), Model komunikasi pemasaran yang biasa dikembangkan pada umumnya tidak jauh dengan proses komunikasi dalam ilmu komunikasi. Model komunikasi pemasaran meliputi sender atau disebut juga sumber (source). Seperti gambar dibawah ini.

\footnotetext{
${ }^{1}$ William J. Stanton, Prinsip-prinsip Pemasaran (Jilid VII; Jakarta: Erlangga, 2001), h. 23.
} 


\section{Gambar 1}

Model Komunikasi Pemasaran

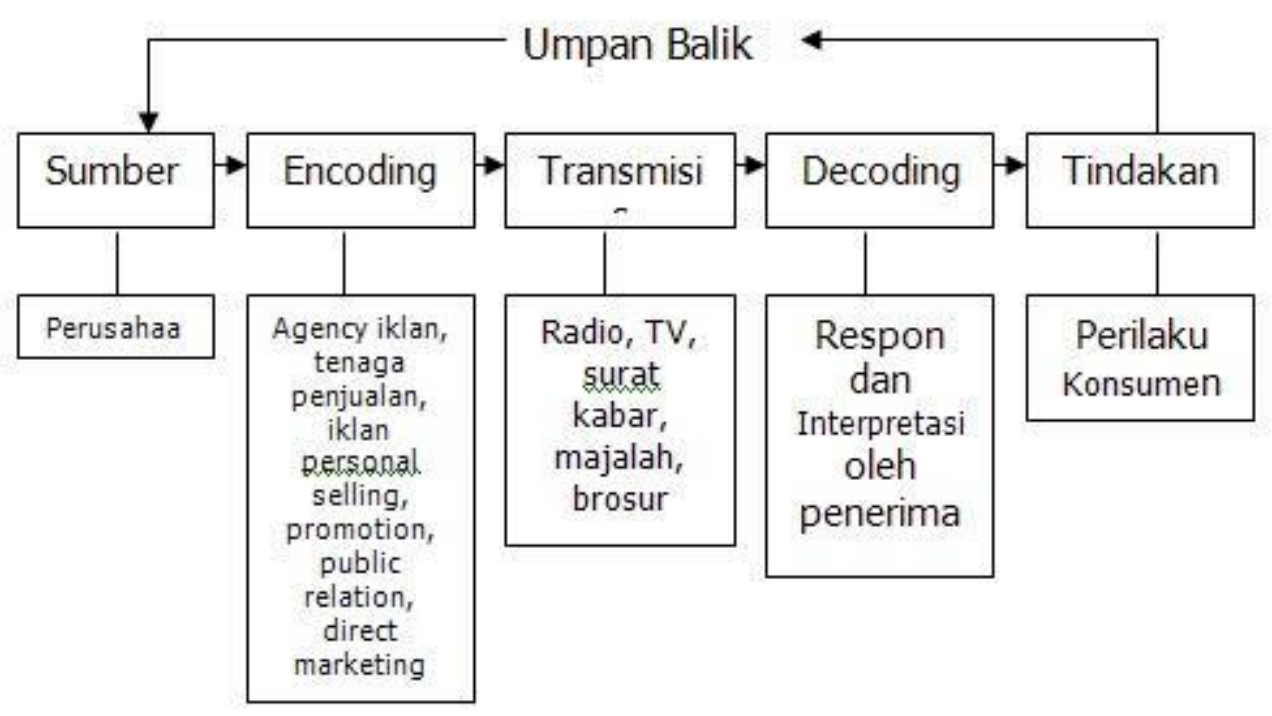

\section{Sumber: Sutisna, 2001: 270}

Sumber berarti pihak yang mengirim pesan pemasaran kepada konsumen. Pihak yang mengirim pesan tentu saja perusahaan. Proses selanjutnya yaitu perusahaan menentukan bagaimana pesan itu disusun agar bisa dipahami dan direspons secara positif oleh penerima dalam hal ini konsumen. Pada proses tersebut ditentukan pula jenis komunikasi apa yang akan digunakan. Apakah pesan akan disampaikan melalui iklan, personal selling, promosi penjualan, publik relation atau pemasaran langsung. Proses enconding ini juga disebut sebagai proses menerjemahkan tujuan-tujuan komunikasi ke dalam bentuk-bentuk pesan yang akan dikirimkan kepada penerima.

Proses selanjutnya yaitu menyampaikan pesan melalui media. Jika pesan dirancang dalam bentuk iklan, maka pesan harus disampaikan dalam bentuk media cetak atau media elektronik. Pesan yang disampaikan dalam media cetak akan berbeda bentuk dan strukturnya dengan pesan yang disampaikan dalam media elektronik. Pesan dalam media cetak biasanya bersifat detail dan menjelaskan karakteristik produk secara lengkap. Sedangkan pesan yang akan disampaikan dalam media elektronik seperti radio dan televisi tidak boleh secara detail menerangkan 
produk karena akan sangat memakan biaya. Proses penyampaian pesan melalui media ini disebut sebagai proses transmisi.

Pesan yang disampaikan melalui media akan ditangkap oleh penerima. Ketika pesan diterima, penerima akan memberikan respons terhadap pesan yang disampaikan. Respons yang diberikan bisa positif, negatif atau netral. Respon positif tentu saja adalah respons yang diharapkan oleh pengirim pesan. Respon positif identik dengan terjadinya keserasian antara harapan pengirim pesan dengan tanggapan penerima pesan.

Dengan perkataan lain, pesan yang dirancang direspons sesuai dengan keinginan perancang pesan. Kesesuaian antara harapan pengirim dengan tanggapan penerima inilah yang diharapkan terjadi, karena hal ini akan mempengaruhi perilaku konsumen secara positif. Hal yang tidak diharapkan terjadi adalah respons negatif atau netral dari konsumen (penerima pesan), respon negatif ini terjadi karena tidak terjadinya keserasian antara harapan pengirim pesan dengan respons dilakukan oleh penerima. Pengirim mengharapkan A, konsumen mengharapkan B, jadi ada ketidaksesuaian antara harapan pengirim dengan tanggapan konsumen. Proses memberikan respons dan menginterprestasikan pesan yang diterima disebut sebagai proses decoding. Proses decoding berarti penerima pesan memberi interprestasi atas pesan yang diterima.

Proses decoding ini akan dilanjutkan dengan tindakan konsumen sebagai penerima pesan, jika pesan yang sampai diterima secara positif, maka hal ini akan memberikan pengaruh positif pada sikap dan perilaku konsumen. Sikap positif konsumen terhadap suatu produk akan mendorong konsumen untuk melakukan tindakan pembelian, karena dibatasi oleh kemampuan daya beli. Sedangkan sikap negatif terhadap produk akan menghalangi konsumen untuk melakukan tindakan pembelian. Janganlah sikap negatif, sikap positif pun tidak semuanya diakhiri dengan pembelian, apalagi jika sesorang mempunyai sikap negatif, pasti akan sangat menghalangi tindakan pembelian. Oleh karena itu, pembentukan sikap positif terhadap produk sangat penting dilakukan oleh perusahaan. 
Proses terakhir yaitu umpan balik atas pesan yang dikirimkan. Perusahaan mengevaluasi apakah pesan yang disampaikan sesuai dengan harapan, artinya mendapat respons dan tindakan yang positif dari konsumen atau justru pesan tidak sampai secara efektif. Pengukuran efektifitas pesan adalah tingkat penjualan produk yang ditawarkan ke pasar. Pesan melalui iklan disebut berhasil atau efektif jika tingkat penjualan produk setelah proses penyampaian pesan meningkat secara signifikan. Sebaliknya pesan yang disampaikan tidak efektif jika setelah pesan disampaikan penjualan produk tidak meningkat, atau justru turun. Indikator penjualan ini seharusnya menjadi sinyal awal bagi perusahaan untuk melakukan penelitian atas pesan yang sampaikan ke konsumen.

Terdapat konsep dalam penyampaian pesan dalam pemasaran yang disebut dengan bauran pemasaran. Menurut Kotler, bauran pemasaran merupakan penggabungan dari lima model dalam pemasaran. Di dalam bauran pemasaran ini biasanya sering digunakan berbagai jenis promosi. Terdapat lima jenis promosi yang biasa disebut bauran pemasaran seperti yang dijelaskan diatas, penjualan tatap muka, humas, promosi penjualan, publisitas serta perusahaan langsung. ${ }^{2}$

Kotler, seorang pakar pemasaran, menyebutkan bahwa bauran pemasaran adalah seperangkat alat pemasaran yang digunakan perusahaan untuk terus menerus mencapai tujuan pemasarannya di pasar sasaran. Alat-alat itu diklasifikasikan menjadi empat kelompok yang disebut empat $\mathrm{P}$ (4P) dalam pemasaran : product (produk), price (harga), place (tempat) dan promotion (promosi). ${ }^{3}$

Bauran komunikasi pemasaran adalah kumpulan alat-alat untuk mempromosikan suatu produk, yang terdiri dari:

1. Penjualan perorangan (personal selling)

Penjualan perorangan adalah alat promosi yang efektif dalam membangun preferensi, keyakinan dan tindakan calon pembeli. Alat promosi ini memerlukan biaya yang besar dibandingkan dengan alat promosi lainnya.

${ }^{2}$ Philip Kotler, Manajamen Pemasaran (Jilid 1 dan 2; Jakarta: Indeks, 2005), h. 90.

${ }^{3}$ Philip Kotler, Manajamen Pemasaran (Jilid 1 dan 2; Jakarta: Indeks, 2005), h. 24. 
2. Periklanan (advertising)

Iklan adalah segala bentuk presentasi non-pribadi dan promosi gagasan, barang atau jasa oleh sponsor tertentu yang harus dibayar Periklanan merupakan komunikasi non personal, sehingga mampu menjangkau target konsumen yang lebih besar daripada penjualan perorangan.

3. Promosi penjualan

Promosi penjualan digunakan untuk mendorong tindakan calon konsumen untuk membeli produk yang ditawarkan dalam waktu singkat.

4. Hubungan masyarakat (public relations) dan publisitas (publicity)

Berbagai program yang dirancang untuk mempromosikan atau melindungi citra perusahaan atau masing-masing produknya.

5. Pemasaran Langsung (Direct Marketing)

Pemasaran langsung memiliki ciri-ciri, yaitu pesan ditujukan kepada orang tertentu, pesan dapat disiapkan untuk menarik orang yang dituju, pesan dapat disiapkan dengan sangat cepat (terbaru) dan pesan dapat diubah tergantung tanggapan dari orang tersebut. Surat langsung, pemasaran jarak jauh dan pemasaran elektronik merupakan bentuk pemasaran langsung ${ }^{4}$

\section{Iklan sebagai Platform Pemasaran}

Periklanan adalah segala bentuk penyajian dan promosi ide, barang, atau jasa nonpersonal oleh sesuatu sponsor tertentu yang memerlukan pembayaran. ${ }^{5}$ (Kotler, 1994). Pengertian lain dari iklan adalah merupakan media informasi yang dibuat sedemikian rupa agar dapat menarik minat khalayak, orisinal, serta memiliki karakteristik tertentu dan persuasif sehingga para konsumen atau khalayak secara suka rela terdorong untuk melakukan suatu tindakan sesuai yang diinginkan pengiklan.

Secara umum periklanan mempunyai fungsi komunikasi yang paling

${ }^{4}$ Philip Kotler, Manajamen Pemasaran (Jilid 1 dan 2; Jakarta: Indeks, 2005), h. 121.

${ }^{5}$ Philip Kotler, Manajemen Pemasaran; Analisis, Perencanaan, Implementasi dan Pengendalian (Salemba Empat, 1994), h. 37. 
penting bagi perusahaan bisnis dan organisasi lainnya yaitu:

a. Informing (memberi informasi) membuat konsumen sadar (aware) akan merek-merek baru, serta memfasilitasi penciptaan citra merek yang positif.

b. Persuading (mempersuasi) iklan yang efektif akan mampu mempersuasi (membujuk) pelanggan untuk mencoba produk atau jasa yang diiklankan.

c. Reminding (mengingatkan) iklan menjaga agar merek perusahaan tetap segar dalam ingatan para konsumen. Periklanan yang efektif juga meningkatkan minat konsumen terhadap merek yang sudah ada dan pembelian sebuah merek yang mungkin tidak akan dipilihnya.

d. Adding Value (memberikan nilai tambah) Periklanan memberikan nilai tambah pada merek dengan mempengaruhi persepsi konsumen. Periklanan yang efektif menyebabkan merek dipandang lebih elegan, bergaya, bergengsi dan lebih unggul dari tawaran pesaing.

e. Assisting (mendampingi) peran utama periklanan adalah sebagai pendamping yang memfasilitasi upaya-upaya lain dari perusahaan dalam proses komunikasi pemasaran. Sebagai contoh, periklanan mungkin digunakan sebagai alat komunikasi untuk meluncurkan promosi-promosi penjualan seperti kupon-kupon dan undian. Peran penting lain dari periklanan adalah membantu perwakilan dari perusahaan. ${ }^{6}$ Iklan yang baik adalah semua tujuan dari periklanan dapat tersampaikan kepada masyarakat. Untuk dibutuhkan iklan yang efektif dan efisien dalam menyampaikan pesan.

Perkembangan tekhnologi mempengaruhi perkembangan periklanan juga. Yang paling mempengaruhi dalam perkembangan iklan adalah kemajuan dari tekhnologi informasi yang membuat bentuk dari iklan sangat beraneka ragam.

Periklanan yang efektif yaitu apabila ia mencapai tujuan-tujuan yang ingin dicapai oleh pengiklan. ${ }^{7}$ (Shimp, 2003). Banyak pengiklan menggunakan media televisi, dikarenakan televisi adalah media yang menggunakan penggabungan dari

${ }^{6}$ Terence A. Shimp, Komunikasi Pemasaran Terpadu dalam Periklanan dan Promosi. Jakarta: Salemba Empat,, 2014), h. 54.

${ }^{7}$ Terence A. Shimp, Komunikasi Pemasaran Terpadu dalam Periklanan dan Promosi, h. 64. 
audio, visual, dan gerak. Berbeda dengan media seperti koran dan radio yang hanya menampilkan audio atau visual saja. Dengan media televisi pengiklan dapat mempengaruhi indera pendengaran maupun penglihatan sekaligus sehingga dapat dengan mudah merangsang otak masayarakat. Maka dari itu diharapkan televisi tersebut dapat mempengaruhi minat beli konsumen terhadap produk yang ditawarkan.

Iklan yang efektif memiliki beberapa pertimbangan sebagai berikut:

a. Iklan harus memperpanjang suara strategi pemasaran. Iklan bisa jadi efektif hanya bila cocok dengan elemen lain dari strategi komunikasi pemasaran yang diarahkan dengan baik dan terintegrasi.

b. Periklanan yang efektif harus menyatakan sudut pandang konsumen. Para konsumen membeli manfaat-manfaat produk, bukan atribut atau lambangnya. Oleh karena itu, iklan harus dinyatakan dengan cara yang berhubungan dengan kebutuhan-kebutuhan, keinginannya, serta apa yang dinilai oleh konsumen.

c. Periklanan yang efektif harus persuasif. Persuasi biasanya terjadi ketika produk yang diiklankan dapat memberikan keuntungan tambahan bagi konsumen.

d. Iklan harus menemukan cara yang unik untuk menerobos kerumunan iklan. Para pengiklan secara kontinyu berkompetisi dengan para pesaingnya dalam menarik perhatian konsumennya.

e. Iklan yang baik tidak menjanjikan lebih dari apa yang bisa diberikan. Intinya adalah menerangkan dengan apa adanya, baik dalam pengertian etika serta dalam pengertian bisnis yang cerdas.

f. Iklan yang baik mencegah ide kreatif dari strategi yang berlebihan. Tujuan iklan adalah mempersuasi dan mempengaruhi. Penggunaan humor yang tidak efektif mengakibatkan orang hanya ingat humornya saja, tetapi melupakan pesannya. ${ }^{8}$

Kemajuan tekhnologi membuat iklan semakin bervariatif. Hal ini

\footnotetext{
${ }^{8}$ Terence A. Shimp, Komunikasi Pemasaran Terpadu dalam Periklanan dan Promosi, h. 71.
} 
menuntut pengiklan untuk membuat iklan yang kreatif agar berbeda dari iklan yang lain. Iklan yang baik adalah iklan yang memiliki daya tarik, agar masyarakat yang melihat tertarik dengan isi dari iklan.

\section{Proses Manajemen Periklanan}

Iklan yang efektif harus terdapat lima unsur yang disebut lima (5) M, seperti yang termuat pada gambar berikut :

Gambar 2

Lima $\mathrm{M}$ dalam Periklanan

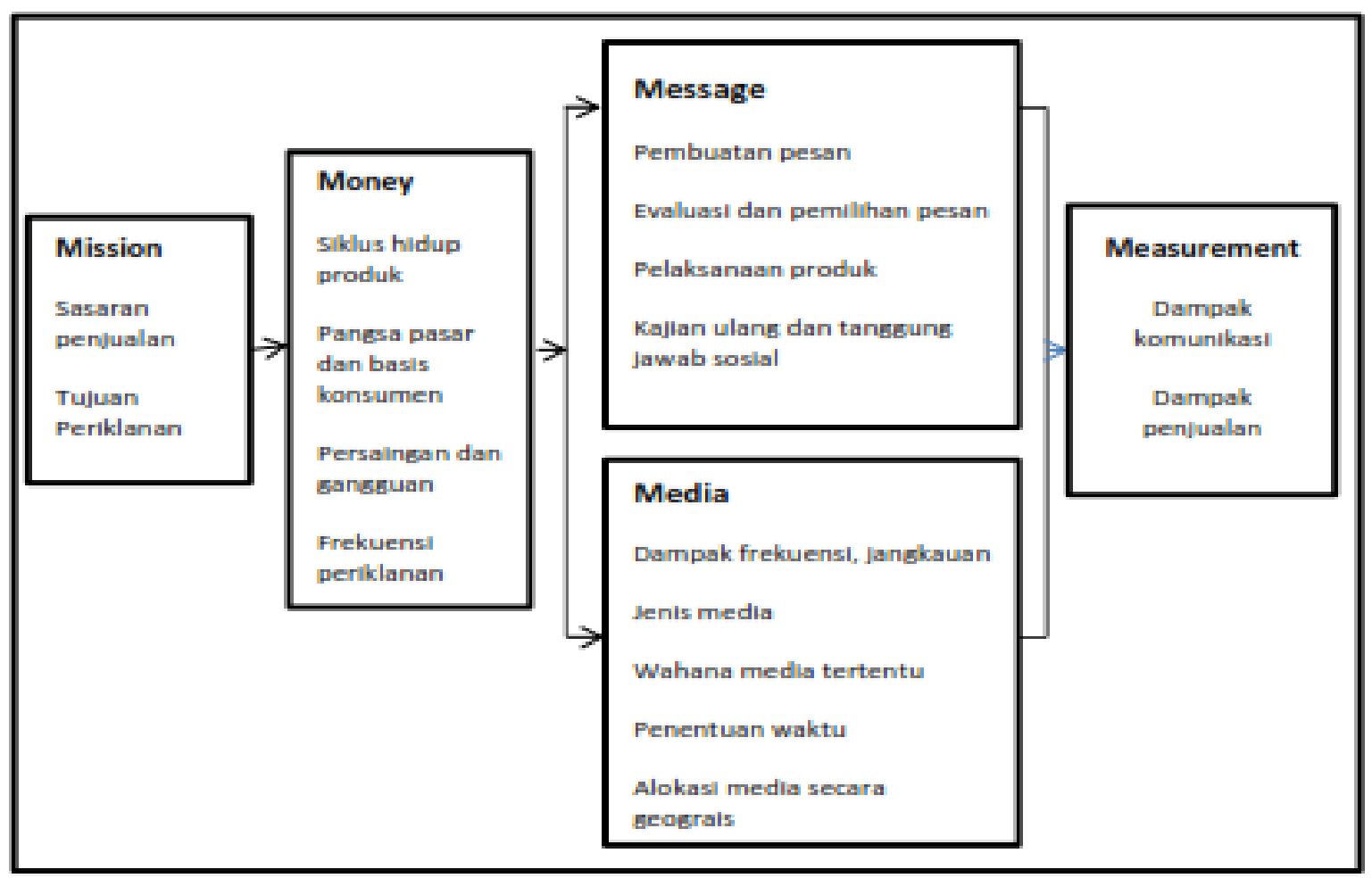

Mission merupakan unsur awal yang membentuk lima M, mission merupakan sebuah tujuan dibuatnya iklan serta sasaran dari penjualan produk yang dipromosikan melalui iklan. ${ }^{9}$ Tujuan periklanan menginduk yang baik seharusnya mampu menunjukkan hubungan terhadap tingkat penjualan. Secara umum, perusahaan mengiklan produknya dalam rangka berikut:

${ }^{9}$ Philip Kotler, Manajamen Pemasaran (Jilid 1 dan 2; Jakarta: Indeks, 2005), h. 129,. 
a. Menciptakan kesadaran pada suatu merek di benak konsumen (create awareness). Brand Awareness yang tinggi merupakan kunci pembuka untuk tercapainya brand equity yang kuat. Pemasar seharusnya menyadari bahwa tanpa brand awareness yang tinggi, sulit mendapatkan pangsa pasar yang tinggi.

b. Mengkomunikasikan informasi kepada konsumen mengenai atribut dan manfaat suatu merek (communicate information about attributes and benefits).

c. Mengembangkan atau mengubah citra atau personalitas sebuah merek (develop or change an image or personality). Sebuah merek terkadang mengalami dilusi, sehingga perlu diperbaiki citranya. Yang dapat dilakukan adalah melaksanakan program pengiklanan.

d. Mengasosiasikan suatu merek dengan perasaan dan emosi (associate a brand with feeling and emotions). Hal ini bertujuan agar ada hubungan emosi antara konsumen dan suatu merek.

e. Menciptakan norma-norma kelompok (create group norms).

f. Mengendapkan perilaku (precipate behaviour).

g. Mengarahkan konsumen untuk membeli produknya dan mempertahankan market power perusahaan.

h. Menarik calon konsumen menjadi konsumen yang loyal dalam jangka waktu tertentu.

i. Mengembangkan sikap positif calon konsumen yang diharapkan dapat menjadi pembeli potensial di masa mendatang. ${ }^{10}$

\section{Anggaran Periklanan}

Ada lima faktor yang peelu diperhatikan dalam penetapan anggaran iklan:

a. Tahapan siklus produk

10 Durianto, Darmadi, dkk, Invasi Pasar Dengan Iklan Yang Efektif. (Jakarta: Gramedia Pustaka Utama, 2003), h. 73. 
Pada umumnya produk baru memerlukan anggaran iklan yang besar dalam rangka membangun kesadaran dan membuat konsumen berkenan mencoba produk tersebut. Sedangkan produk yang sudah mapan, biasanya memerlukan anggaran periklanan yang rendah.

b. Pangsa pasar dan basis konsumen

Merek dengan pangsa pasar yang tinggi, biasanya membutuhkan lebih sedikit biaya iklan sebagai persentase penjualan untuk mempertahankan pangsanya.

c. Persaingan dan gangguannya

Pangsa pasar dengan persaingan ketat dan tingkat gangguan yang tinggi, suatu merek harus diiklankan secara besar-besaran, agar gaungnya terdengar, sehingga mampu meredam gangguangangguan yang diciptakan pesaing.

d. Frekuensi periklanan

Ferkuensi periklanan berkaitan dengan jumlah pengulangan tayangan yang diperlukan untuk menyampaikan pesan ke konsumen. Frekuensi periklanan sangat menentukan anggaran periklanan.

e. Kemungkinan subtitusi produk

Jika suatu merek memiliki banyak produk substitusi, maka memerlukan anggaran iklan yang cukup besar untuk menciptakan suatu diferensiasi substansial. ${ }^{11}$

\section{Pesan dan Iklan}

Pesan adalah setiap pemberitahuan, kata, atau komunikasi baik lisan maupun tertulis, yang dikirimkan dari satu orang ke orang lain yang mewakili perasaan, nilai, gagasan, atau maksud sumber yang menyampaikan. Pesan memiliki tiga komponen yaitu makna, simbol yang digunakan untuk menyampaikan makna, dan bentuk atau organisasi pesan. ${ }^{12}$ Orang melakukan komunikasi dikarenakan orang tersebut memiliki suatu pesan atau informasi yang ingin disampaikna kepada orang lain.

${ }^{11}$ Philip Kotler, Manajamen Pemasaran (Jilid 1 dan 2; Jakarta: Indeks, 2005), h. 134.

${ }^{12}$ Dedi Mulyana, Pengantar Ilmu Komunikasi (Bandung: Remaja Rosdakarya, 2000), h. 32. 
Begitu juga dalam beriklan, dimana pengiklan bermaksud ingin menyampaikan pesan atau informasi kepada masyarakat. Iklan yang baik biasanya difokuskan pada satu penjualan inti, berisi hal-hal yang menarik dari merek yang diiklankan, menyatakan suatu yang eksklusif, berbeda dan tidak akan dijumpai di merek yang lainnya, serta dapat menyakinkan atau dibutuhkan konsumen.

Agar pesan iklan dapat dengan mudah dimengerti oleh konsumen maka iklan harus menggunakan kata-kata yang tepat dalam menyampaikan pesan. Ilustrasi yang menarik juga sering digunakan pengiklan untuk membantu mempermudah konsumen dalam memahami pesan yang disampaikan.

Iklan yang baik harus meningalkan kesan bagi para penontonnya. Kesan adalah apa yang orang pikir pertama kali ketika melihat iklan tersebut. Jika kesan pertama kali masyarakat terhadap iklan tersebut baik, maka dapat dipastikan pesan yang disampaikan oleh iklan tersebut akan selalu diingat oleh masyarakat. Agar iklan tersebut mendapatkan kesan yang baik maka iklan harus menginformasikan kelebihan akan produk yang tidak sama dengan kelebihan produk pesaing. Sehingga diharapkan terdapat perbadaan dengan iklan-iklan pesaing yang telah beredar.

\section{Media Iklan}

Banyak macam media dalam beriklan, diantaranya ada media cetak dan elektronik. Contoh dari media cetak ada koran, majalah, spanduk, baliho, dan lainlain, sedangkan media elektronik ada televisi, radio, dan internet. Dalam setiap media memiliki kelebihan dan kelemahan masing-masing. Untuk itu perlu dilakukan manajemen dalam pemilihan media dalam beriklan agar kelebihan dari media iklan dapat dimaksimalkan. Tidak jarang juga pengiklan beriklan di berbagai media jika dirasa kurang dapat memaksimalkan hanya dari satu media saja. Dikenal dengan istilah media mix, yaitu penggunaan dua atau lebih media yang berbeda dalam periklanan.

Tabel 2.1

Keunggulan dan Kelemahan Jenis-jenis Media 


\begin{tabular}{|c|c|c|}
\hline Media & Keunggulan & Kelemahan \\
\hline Koran & $\begin{array}{l}\text { Fleksibel, tepat waktu, dipercaya, } \\
\text { diterima luas dan local market } \\
\text { coverage. }\end{array}$ & $\begin{array}{l}\text { Tidak awet, mutu reproduksi } \\
\text { rendah dan pass-along } \\
\text { audiens rendah. }\end{array}$ \\
\hline Televisi & $\begin{array}{l}\text { Gabungan penglihatan bunyi dan } \\
\text { gerak, menggelitik panca indera, } \\
\text { atensi tinggi dan jangkauan luas. }\end{array}$ & $\begin{array}{l}\text { Biaya absolut tinggi, high } \\
\text { clutter, fleeting exposure dan } \\
\text { selektifitas audiens kurang. }\end{array}$ \\
\hline Direct mail & $\begin{array}{l}\text { Audiens terseleksi, fleksibel dan } \\
\text { tidak ada pesaing dalam medium } \\
\text { yang sama dan personalisasi. }\end{array}$ & $\begin{array}{l}\text { Biaya agak tinggi dan citra } \\
\text { surat sampah }\end{array}$ \\
\hline Radio & $\begin{array}{l}\text { Massa, demografis, biaya rendah } \\
\text { dan seleksi geografis. }\end{array}$ & $\begin{array}{l}\text { Audio saja, atensi rendah } \\
\text { dibanding televisi, struktur } \\
\text { tarif tak baku dan fleeting } \\
\text { exposure. }\end{array}$ \\
\hline Majalah & $\begin{array}{l}\text { Seleksi geografis dan demografis, } \\
\text { kredibel dan prestasi, reproduksi, } \\
\text { bermutu, awet dan good pass } \\
\text { along readership. }\end{array}$ & $\begin{array}{l}\text { Antrian giliran iklan, } \\
\text { sebagian sirkulasi sia-sia dan } \\
\text { tidak ada jaminan posisi } \\
\text { iklan. }\end{array}$ \\
\hline Luar ruang & $\begin{array}{l}\text { Fleksibel, exposureberulang, } \\
\text { biaya rendah dan persaingan } \\
\text { rendah. }\end{array}$ & $\begin{array}{l}\text { Selektifitas terbatas dan } \\
\text { kreatifitas terbatas. }\end{array}$ \\
\hline $\begin{array}{c}\text { Halaman } \\
\text { kuning }\end{array}$ & $\begin{array}{l}\text { Local coverage bagus, dipercaya, } \\
\text { jangkauan luas dan biaya rendah. }\end{array}$ & $\begin{array}{l}\text { Persaingan tinggi, antrian } \\
\text { lama dan kreatifitas terbatas. }\end{array}$ \\
\hline Newsletter & $\begin{array}{l}\text { Selektifitas tinggi, kendali penuh, } \\
\text { peluang interaktif dan biaya } \\
\text { rendah. }\end{array}$ & Biaya tidak terkontrol. \\
\hline Brosur & $\begin{array}{l}\text { Fleksibel, kendali penuh dan } \\
\text { dapat mendramatisir pesan. }\end{array}$ & $\begin{array}{l}\text { Produksi berlebihan dapat } \\
\text { membuat biaya tidak } \\
\text { terkontrol. }\end{array}$ \\
\hline Telefon & $\begin{array}{l}\text { Banyak pengguna dan peluang } \\
\text { untuk sentuhan pribadi. }\end{array}$ & $\begin{array}{l}\text { Biaya relatif tinggi, kecuali } \\
\text { menggunakan sukarelawan. }\end{array}$ \\
\hline Internet & $\begin{array}{l}\text { Selektifitas tinggi dan interaktif, } \\
\text { serta biaya rendah. }\end{array}$ & $\begin{array}{l}\text { Media baru dengan pemakai } \\
\text { terbatas. }\end{array}$ \\
\hline
\end{tabular}




\section{Kesadaran Merek}

Kesadaran merek adalah kesanggupan calon pembeli untuk mengenali, mengingat kembali suatu merek sebagai bagian dari kategori produk tertentu. Tingkatan dari kesadaran merek sebagai berikut:

a. Tidak menyadari merek (unaware brand)

Tingkat ini merupakan tingkat yang paling rendah dalam kesadaran merek. Pada posisi ini konsumen sama sekali tidak menyadari keberadaan produk.

b. Pengenalan merek (brand recognition)

Pada tingkat ini, konsumen mengenal merek produk, tetapi diperlukan bantuan untuk mengingatnya.

c. Pengingatan kembali merek (brand recall)

Tingkat pengingatan kembali merek didasarkan pada permintaan seseorang untuk menyebutkan merek tertentu dalam suatu kelas produk. Hal ini diistilahkan dengan pengingatan kembali tanpa bantuan.

d. Puncak pikiran (top of mind)

Apabila seseorang ditanya langsung tanpa diberi bantuan pengingatan dan dapat menyebutkan satu nama merek, maka merek tersebut merupakan puncak pikiran. Dengan kata lain, merek tersebut merupakan merek utama dari berbagai merek yang ada di benak konsumen. ${ }^{13}$

\section{HASIL DAN PEMBAHASAN}

Ramadhan menjadi moment untuk melakukan berbagai kegiatan pemasaran, salah satunya adalah yang dilakukan oleh Tokopedia melalui iklan Ramadhan versi pasrah. Pada iklan ini, Tokopedia berusaha untuk mengangkat kejadian yang dapat dikatakan 'sering' terjadi di masjid tanpa bermaksud untuk menyinggung SARA.

Namun iklan ini justru menuai dua pendapat yang cukup kontroversi. Ada yang

${ }^{13}$ Durianto, Darmadi, dkk, Invasi Pasar Dengan Iklan Yang Efektif. (Jakarta: Gramedia Pustaka Utama, 2003), h. 82. 
merasa terhibur dan ada yang merasa tersingung. Keduanya melihat dari dua sudut pandang yang berbeda. Beberapa orang yang berpendapat terhibur, melihat bahwa iklan ini tidak biasa, mereka tidak menduga bahwa adegan selanjutnya adalah kehilangan sandal, lucu meski ada beberapa yang merasa bingung, apa hubungannya sandal hilang dengan Tokopedia. Beberapa orang yang merasa tersingung, karena seakan menjelek-jelekan Islam secara tidak langsung. Sehingga citra Islam menjadi buruk. Beberapa orang tersebut meminta agar iklan ini tidak lagi ditayangkan, namun iklan ini tetap tayang selama bulan Ramadhan.

Iklan yang baik adalah iklan yang mampu memenuhi semua tujuan dari periklanan sehingga pesan dapat tersampaikan pada sasaran. Untuk dibutuhkan iklan yang efektif dan efisien dalam menyampaikan pesan. Namun dalam kasus ini, sepertinya Tokopedia belum bisa membuat iklan yang efektif dan efisien. Ada beberapa makna yang dapat disimpulkan oleh penerima pesan, seperti (1) Berhati-hati bila datang ke masjid; (2) Kehilangan sandal adalah salah satu ujian di bulan Ramadhan agar kita bisa semakin berpasrah kepada Allah; (3) Bila hilang sandal bisa mencari sandal baru di Tokopedia; dan lain sebagainya. Perbedaan makna ini menjadi bukti ketidakefektifan dari iklan tersebut.

\section{Sinopsis Iklan}

Iklan Tokopedia versi Pasrah yang dipublikasikan pada 7 Juni 2015 yang menceritakan kisah seorang pria yang kehilangan sendalnya di masjid. Pria tersebut digambarkan amat pasrah pada scene-scene awal. Namun kemudian ia terlihat kebingungan mencari pasangan sendalnya yang hilang. Namun kebingungannya terjawab pada scene-scene akhir dengan adanya layanan Tokopedia yang menjual begitu banyak sandal. Berikut beberapa potongan iklan Tokopedia versi pasrah yang selalu ditayangan tepat sebelum adzan berbuka puasa di RCTI. 

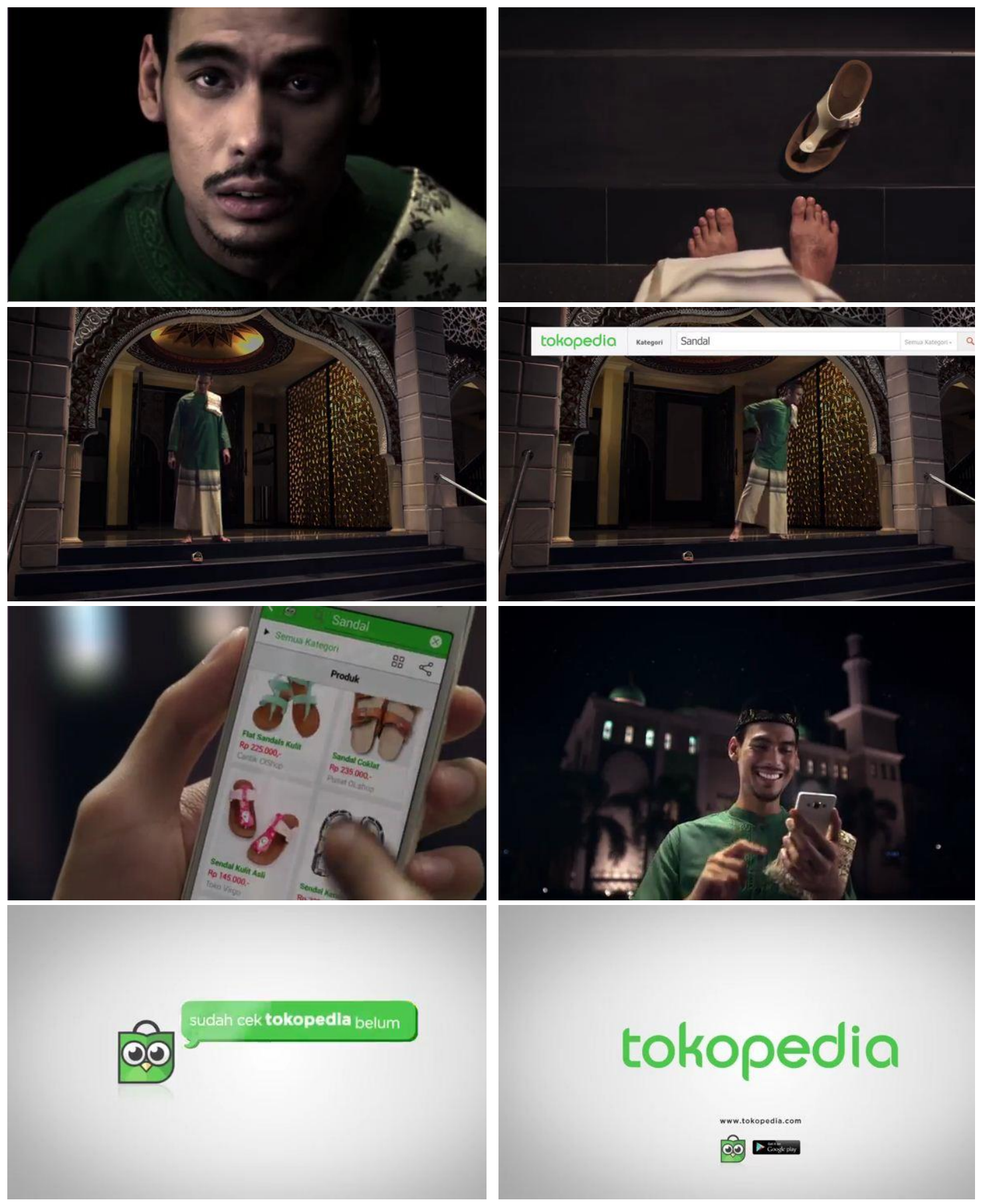

Tokopedia sekan dapat memenuhi kebutuhan setiap orang. Sebab Tokopedia menjual berbagai hal, tidak hanya sandal. Itulah pesan yang ingin disampaikan oleh Tokopedia, sesuai dengan tagline-nya "Sudah cek tokopedia belum?". 


\section{Analisis Iklan}

Dalam analisis ini penjelasan akan mencakup tipe \& tujuan iklan, persepsi, analisa iklan, dan juga dampak iklan .

\section{a. Tipe dan Tujuan iklan}

Tiap iklan mempunyai tipe dan tujuan iklan yang berbda. Begitu pula dengan iklan Tokopedia "Pasrah" ini termasuk kepada iklan yang komersial atau menjual. Tipe iklan komersial bertujuan agar penonton membeli produk yang ditayangkan. Tidak hanya itu tipe iklan ini juga bertujuan untuk mempengaruhi dan membentuk realitas baru bagi penonton. Dalam iklan ini, perancang iklan mampu menarik perhatian banyak orang .

Sementara di lihat dari fungsi iklan, secara umum periklanan mempunyai fungsi komunikasi, yaitu memberikan informasi, mempersuasi, mengingatkan, memberikan nilai tambah dan mendampingi.

1. Informing - Tokopedia melalui iklan yang ditayangkan melalui media televisi dengan durasi 30 detik memberikan informasi kepada konsumen (aware) tentang keberadaan jasanya sebagai mall online yang menjual berbagai produk. Namun, karena penggambaran yang kurang tepat, sehingga menimbulkan pemaknaan yang berbeda-beda sehingga pesan tidak tersampaikan dengan efektif.

2. Persuading-Tokopedia melalui tagline-nya mampu mempersuasi konsumen untuk mencoba menggunakan layanan belanja online "Sudah cek tokopedia belum?”.

3. Reminding-Ada tiga iklan sejenis yang telah dipublikasikan oleh Tokopedia dengan versis yang berbeda-beda tentunya. Dan kali ini iklan versi pasrah diluncurkan untuk memenuhi moment Ramadhan dimana kaum Muslimin diuji tidak hanya menahan lapar dan dahaga tetapi juga hawa nafsu dan kepasrahan. Iklan ini tayang sebelum adzan magrib berkumandang. Saat dimana kaum Muslimin menunggu saatnya berbuka puasa. Ini menjadi moment tepat dan efektif. 
4. Adding Value-Bagi sebagian orang yang berpandangan negative akan iklan ini yang menganggap telah melecehkan Islam justru menjadi boomerang bagi Tokopedia. Sebaliknya melalui iklan ini, Tokopedia belum mampu memberikan nilai tambah untuk memperkuat brandnya.

5. Assisting (mendampingi) - iklan ini belum dapat berfungsi untuk mendampingi, sebab iklan ini hanya lebih kepada brand awareness untuk publik.

\section{PENUTUP}

Dari pembahasan dan analisis di atas, iklan ini dinilai masih belum cukup efektif untuk menyampaikan pesan meski iklan ini cukup menghibur untuk sebagian orang. Tetapi pesan yang disampaikan menjadi kabur sebab begitu banyak makna yang dapat tercipta dari iklan singkat berdurasi 30 detik tersebut. Namun setidaknya iklan ini tetap dapat memenuhi fungsi sebagai brand awareness.

\section{DAFTAR PUSTAKA}

Ardianto, Elvinaro. (2011). Metodelogi Penelitian untuk Public Relation Kuantitatif dan Kualitatif. Bandung : Simbiosa Rekatama Media.

Durianto, Darmadi, dkk. (2003). Inovasi Pasar Dengan Iklan Yang Efektif. Jakarta : Gramedia Pustaka Utama

Jefkins, Frank. (1997). Periklanan. Jakarta : Erlangga

Kotler, Philip. (2005). Manajamen Pemasaran, Jilid 1 dan 2. Jakarta: Indeks

Mulyana, Dedi. (2000). Pengantar Ilmu Komunikasi. Bandung : Remaja Rosdakarya

Shimp, Terence A. (2014). Komunikasi Pemasaran Terpadu dalam Periklanan dan Promosi. Jakarta : Salemba Empat.

Suhandang, Kustadi. (2005). Periklanan : Manajemen, Kiat dan Strategi. Bandung : Nuansa

Sutisna. (2001). Perilaku Konsumen \& Komunikasi Pemasaran. Bandung : Remaja Rosdakarya 
Website :

https://www.tokopedia.com/

https://id-id.facebook.com/tokopedia

https://id.wikipedia.org/wiki/Tokopedia

https://www.youtube.com/user/tokopedia

https://blog.tokopedia.com/ 